\title{
Historical and Prospective Aspects of Thermally Sprayed Coatings
}

\section{II :TBC Damage in Gas Turbines and Damage Mechanisms}

by

\author{
Akihiro ITO* and Taiji TORIOGE**
}

Key words: Thermal Barrier Coating, Gas Turbine, Damage mechanism, Thermally Grown Oxide

\section{1 緒言}

遮熱コーティング (Thermal Barrier Coating : TBC) は, 高い遮熱性（低熱伝導性）を有するセラミックスを成膜 することで冷却部品のメタル温度を低下させ，耐久性や 信頼性を向上する技術であり，現在の高温ガスタービン

(Gas Turbine：GT) では必須の技術となっている ${ }^{1)}$.

図 1 に, TBC の遮熱効果の原理模式図 ${ }^{1)}$ を示す. 現在, 発電用 GT のタービン入口ガス温度は $1650^{\circ} \mathrm{C}$ に達し, そ の高温化を担うキー技術の一つが TBC とされている2).

TBC は，航空機エンジンから実用化が進められ，1960 年代より使用されている. 表 1 に, 航空機エンジンメー カである Pratt \& Whitney 社 (P\&W 社) の航空機用 TBC 開発の変遷 ${ }^{3)}$ を示す。当初， $\mathrm{TBC}$ のトップコートとして は，マグネシア安定化ジルコニア（Magnesia Stabilized Zirconia：MSZ）が用いられていたが，トップコートの 材質として高温安定性の観点から，現在，イットリア部 分安定化ジルコニア（Yttria Stabilized Zirconia：YSZ）が 用いられている.トップコートの施工法としては電子ビ 一ム物理蒸着法 (Electron Beam-Physical Vapor Deposition：EB-PVD）や大気圧プラズマ溶射法 (Atmospheric Plasma Spray：APS）が主に使用されてい る.

一方，発電用 GT では，材質は航空機用と同様に主に YSZ が多く使用されているが，EB-PVDにより施工され たトップコートは APS で施工されたものに比べて, 遮熱 性, 施工性およびコスト等の観点から一般的には使用さ れておらず, APSによる TBC が主流となっており ${ }^{1)}$, 熱 応力緩和を目的としトップコートに縦割れ（縦方向き 裂）を導入した $\mathrm{TBC}^{4)}$ (Dense Vertically Cracked-TBC : DVC-TBC）も一部で使用されている.

図 2 に, APS および EB-PVD 施工によるタービン翼用 $\mathrm{TBC}$ の断面ミクロ組織の例を示す。いずれも, ボンドコ 一トには耐酸化性に優れた MCrAlY（M : Ni，Co，CoNi 等）合金が，低圧プラズマ溶射法（Low Pressure Plasma Spray : LPPS) や，超高速フレーム溶射法（High Velocity Oxygen-Fuel spray : HVOF）にて施工されている. APS による TBC では, トップコート中に多数の気孔が導入 され，遮熱性を高めることができる。一方，EB-PVDに よる TBC では, トップコートが柱状晶になり，遮熱性
はAPS に比較して劣るものの, 高い熱応力緩和性を有す ることから, 熱サイクル耐久性に優れる特徴を有してい る. TBC は, 高い遮熱性と信頼性を兼備する必要があり, 多くの材料開発および製造技術開発が進められている.

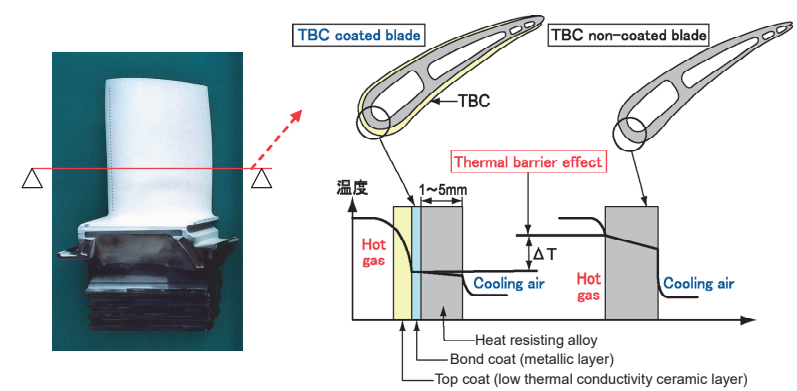

図 1 GT 翼に施工された $\mathrm{TBC}$ とその機能 ${ }^{1)}$

表 $1 \quad \mathrm{P} \& W$ 社における $\mathrm{TBC}$ 開発の変遷 ${ }^{3)}$

\begin{tabular}{|c|c|c|c|c|c|}
\hline TBC system & $\begin{array}{c}\text { Year of } \\
\text { introduction }\end{array}$ & Bondcoat & $\begin{array}{c}\text { Ceramic } \\
\text { topcoat }\end{array}$ & Design of layers & Label \\
\hline $\begin{array}{c}\text { Early } \\
\text { combustor TBC }\end{array}$ & 1963 & $\begin{array}{c}\text { Flame sprayed } \\
\text { Ni-Al }\end{array}$ & $\begin{array}{c}\text { APS } \\
22 \mathrm{MSZ}\end{array}$ & $\begin{array}{c}\text { Ceramic } \\
\text { /Bond coat }\end{array}$ & - \\
\hline$\prime \prime$ & 1973 & $\begin{array}{c}\mathrm{APS} \\
\mathrm{Ni}-\mathrm{Cr} / \mathrm{Al}\end{array}$ & $\begin{array}{c}\text { APS } \\
22 \mathrm{MSZ}\end{array}$ & $\begin{array}{c}\text { Ceramic/Cermet } \\
\text { /Bond coat }\end{array}$ & - \\
\hline$\prime \prime$ & 1974 & $\begin{array}{c}\mathrm{APS} \\
\text { CoCrAlY }\end{array}$ & $\begin{array}{c}\mathrm{APS} \\
22 \mathrm{MSZ}\end{array}$ & Graded & - \\
\hline Gen I & 1984 & $\begin{array}{c}\text { APS } \\
\text { NiCoCrAlY }\end{array}$ & $\begin{array}{c}\text { APS } \\
\text { 22MSZ }\end{array}$ & $\begin{array}{c}\text { Ceramic } \\
\text { /Bond coat }\end{array}$ & PWA261 \\
\hline GiCoCrAlY & $\begin{array}{c}\text { AYSZ } \\
\text { Ceramic } \\
\text { /Bond coat }\end{array}$ & PWA265 \\
\hline Gen III & 1982 & $\begin{array}{c}\text { LPPS } \\
\text { NiCoCrAlY }\end{array}$ & $\begin{array}{c}\text { APS } \\
\text { 7YSZ }\end{array}$ & $\begin{array}{c}\text { Ceramic } \\
\text { /Bond coat }\end{array}$ & PWA264 \\
\hline
\end{tabular}

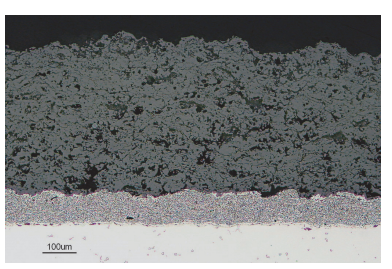

(a)APS

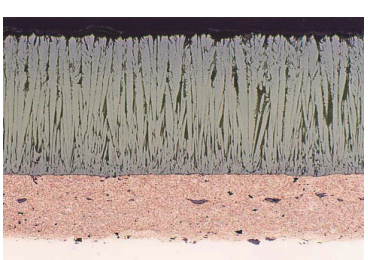

(b)EB-PVD
図 2 代表的な $\mathrm{TBC} の$ 断面ミク口組織の例

+ 原稿受理 令和2年7月7日 Received July 7, 2020 C2021 The Society of Materials Science, Japan

* 正 会 員 中部電力㑣)電力技術研究所 ₹459-8522 名古屋市緑区大高町, Research and Development Center, Chubu Electric Power Co., Inc., Odaka-cho, Midori-ku, Nagoya, 459-8522

** 三菱重工業(侏総合研究所 $\bar{T} 676-8686$ 高砂市荒井町, Research and Innovation Center, Mitsubishi Heavy Industries, Ltd. Arai-cho, Takasago, 676-8686 
加えて, 熱一機械的応力作用下での TBC の強度評価 と材質経年変化の両方を勘案した評価が進められてお り，いわゆる “TBC を使いこなす技術”の開発も進めら れている.

本講座では，実機で経年使用した TBC の損傷・劣化 事例, TBC の損傷メカニズムおよびその評価手法の例に ついて概要を述べる.

\section{TBC の実機での損傷事例}

国内の電力会社では，熱効率が高く，負荷追従性およ び環境性に優れることから, LNG を燃料とする GT コン バインドサイクル (Combined Cycle : CC) 発電プラント を積極的に導入してきた. GTCC 発電プラントの GT 翼 は，使用環境が厳しく，経年使用により先端部に酸化や エロージョンによる減肉，プラットホームにき裂などの 損傷が生じることから，定期的な修理を実施している 5),6).

図 3 に，実機で使用した GT 翼およびその翼面に APS 施工された TBC の損傷・劣化事例 5)を示す. トップコー トには YSZ, ボンド (アンダー) コートには CoNiCrAlY 合金からなる多孔質 $\mathrm{TBC}$ が, 翼面等に施工されている. 実機で使用した GT 翼は, 翼面腹側などで黒色を呈し, 図 3(b)に示すように, 前縁部や先端部において僅かな TBC のはく離が観察され, 黒色部の翼面には亀甲状微細 き裂が観察されている6)

図 4 に, 軽微な TBC のはく離が認められた GT 翼にお ける $\mathrm{TBC}$ の断面ミクロ組織 7)を示す. トップ／ボンドコ 一ト界面近傍には，平行に進展する横方向のき裂が認め られ，トップコート上部には付着物が，ボンドコートに は実機使用中に生成した熱成長酸化物（Thermally Grown Oxide：TGO）が観察される。TGOについては，第 3 章 で概説する.

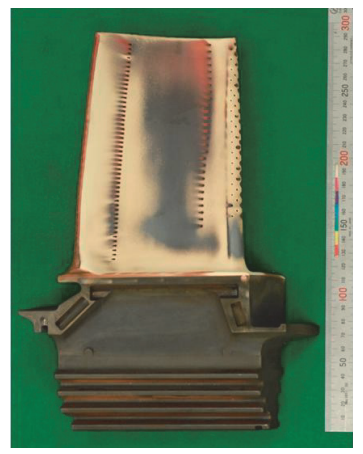

(a)外観

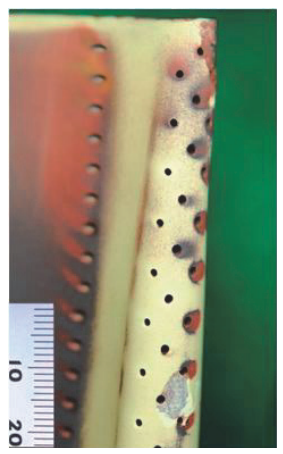

(b)TBC のはく離
図 3 実機で使用した GT 翼の損傷事例 6)

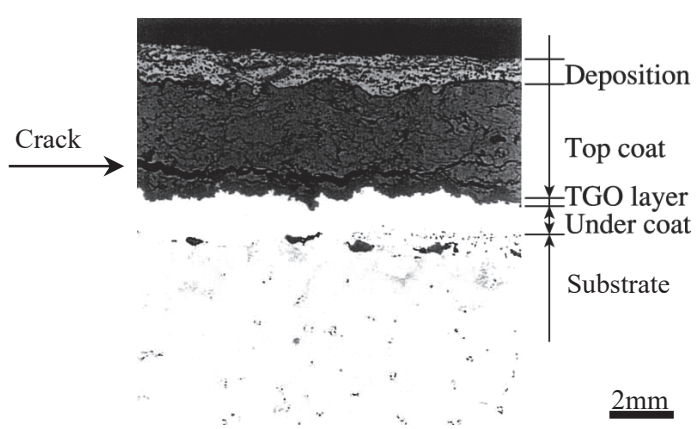

困4 実機使用GT翼におけるTBCの断面ミクロ組織7)
図 5 に, 発電用 GT 翼で使用された DVC-TBC の断面 ミクロ組織 ${ }^{8)}$ を示す. トップコートには YSZ, ボンドコ ートには CoNiCrAlY 合金からなる DVC-TBCが翼面等に 施工され, 翼面腹側の黒色部等で亀甲状微細き裂が観察 されている. TBC には，ボンドコート中にトップコート から進展した縦割れおよびトップ／ボンドコート界面 近傍に横方向き裂は観察されないものの, トップコート 中に横方向き裂が僅かに観察される。このような横方向 き裂が経年使用に伴い連続的に進展すると, TBC のはく 離や脱落につながる可能性がある。

図 6 に，未使用および実機で使用した GT 翼における DVC-TBC の厚さの比較 8)を示す. 実機使用翼腹側のト ップコートは未使用翼に比べて僅かに薄くなっている ことから, TBC 施工時のばらつきだけでなく, 経年使用 によるエロージョンに起因する可能性が考えられる。 エ ロージョンについては, 第 3 章で概説する.

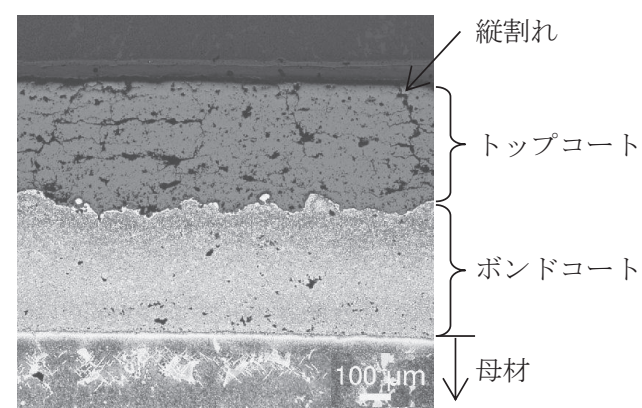

図5＼cjkstart実機使用GT翼におけるDVC-TBCの断面 ミクロ組織8)

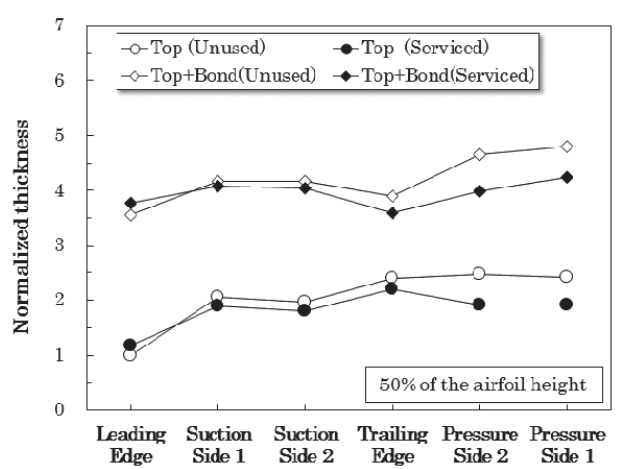

図6 未使用および実機使用GT翼におけるTBCの 厚さの比較 ${ }^{8}$

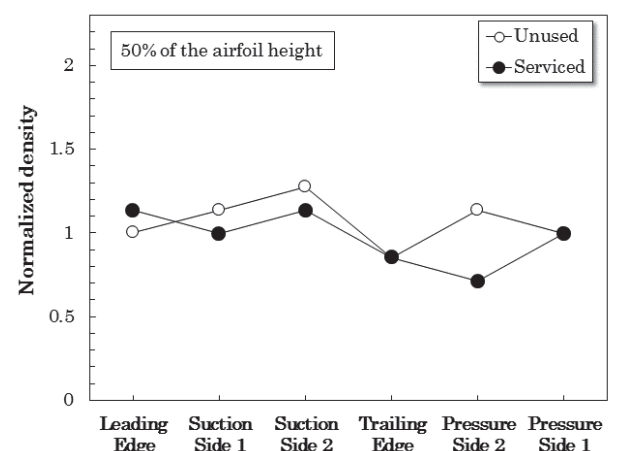

図7 未使用および実機使用GT翼におけるTBC トップコートの縦割れ密度の比較8) 
図 7 に，未使用および実機で使用した GT 翼における

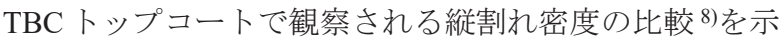
す。実機使用中に縦割れの明瞭な増加は認められないこ とから，縦割れが $\mathrm{TBC}$ のはく離や脱落に影響する可能 性は小さいことが示唆される。

DVC-TBC 施工翼でも，図 4 に示す一般的な TBC と同 様に，界面部には $\mathrm{Al}_{2} \mathrm{O}_{3}$ を主体とする $\mathrm{TGO}$ が観察され， TGO に隣接するボンドコートには析出物が観察されな い $\mathrm{Al}$ 濃度が低い領域（外面 $\mathrm{Al}$ 低下層）が観察される.

\section{TBC の損傷メカニズム}

TBC の損傷やはく離の原因は非常に複雑である. 例え ば，表 2 に，TBC が損傷する際の推定メカニズムについ て Nelson らの報告 9)を示す。これより，TBCの損傷評価 については，多岐にわたったメカニズムについて考えな ければならないことが分かる。

図 8 に, Bose らによる TBC のはく離メカニズム3)を 示す. トップコートの許容圧縮応力に対して，ボンドコ 一トが徐々に酸化してトップコートに与える圧縮応力 と起動・停止に起因する熱サイクルに伴う応力が重畳し た応力が上回った際に TBC にはく離が生じるとしてい る.

表 $2 \mathrm{TBC}$ の損傷/はく離原因として考えら れるメカニズム 9 )

\begin{tabular}{|c|c|}
\hline & Possible mechanism of APS TBC failure \\
\hline $\begin{array}{l}\text { Mechanism with } \\
\text { no time-dependent } \\
\text { accumulation of } \\
\text { damage }\end{array}$ & $\begin{array}{l}\text { - Poor microstructure resulting in high residual stress and/or } \\
\text { low adhesion strength } \\
\text { - High service stresses(e.g. thermal gradients, mechanical } \\
\text { strain, impact) } \\
\text { - Mechanical interface with other components in assembly }\end{array}$ \\
\hline $\begin{array}{l}\text { Mechanism that } \\
\text { increase stress } \\
\text { during service }\end{array}$ & $\begin{array}{l}\text { - Bondcoat oxidation, creation of an interfacial oxide scale } \\
\text { (TGO) } \\
\text { - Densification of YSZ topcoat due to sintering } \\
\text { - Change in YSZ topcoat phase composition } \\
\text { - Relaxation/creep in topcoat, bondcoat or substrate } \\
\text { - Deposits from airborne or fuel-borne contaminants } \\
\text { - Contamination by water or fuel which may volatilize } \\
\text { within the TBC }\end{array}$ \\
\hline $\begin{array}{l}\text { Mechanisms that } \\
\text { reduce strength } \\
\text { during service }\end{array}$ & $\begin{array}{l}\text { - Moisture-assisted slow crack growth (stress corrosion) } \\
\text { - Cyclic fatigue crack growth } \\
\text { - Temperature/time-dependent diffusive crack growth } \\
\text { and/or cavity formation }\end{array}$ \\
\hline $\begin{array}{l}\text { Erosive } \\
\text { mechanisms }\end{array}$ & $\begin{array}{l}\text { Particulate erosion in high velocity gas streams } \\
\text { - Water droplet erosion in water-injected units }\end{array}$ \\
\hline
\end{tabular}

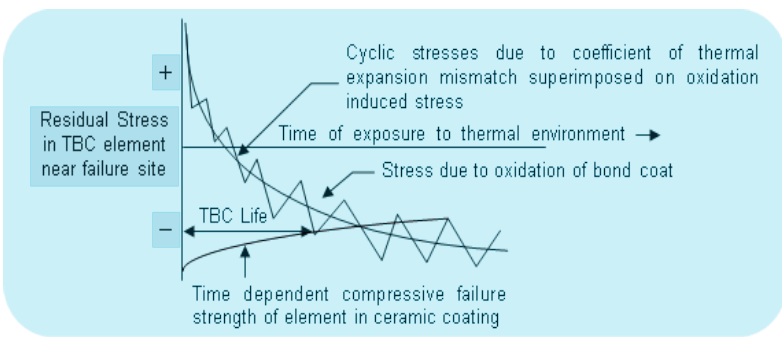

図 8 TBC のはく離メカニズムの例 ${ }^{3)}$

図 9 に，Levi らによる TBC の想定される損傷メカニ ズムの各種形態 ${ }^{10)}$ を示す. TBC の内的要因として, 使用 中の起動・停止の熱応力と TGO の相乗効果によるはく 離, ボンドコートの構成相の変化に伴う凹凸化, 厳しい 熱応力下でのボンドコートの低サイクル疲労によるき 裂等を挙げている。

一方，外的要因として，異物によるエロージョンや FOD (Foreign Object Damage) ならびに CMAS (Calcium-Magnesium-Alumino-Silicate) 等の溶融物が TBC 内に浸透することによる損傷等を挙げている.

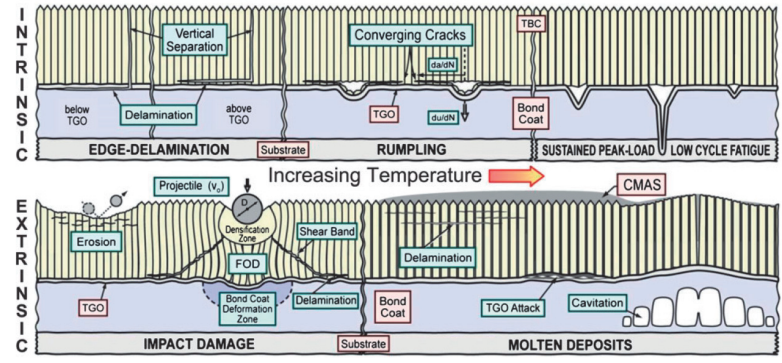

図 9 TBC の想定される損傷メカニズムの各種形態 ${ }^{10}$

以上, 報告されている $\mathrm{TBC}$ の損傷メカニズムのうち, 発電用 GT に重要と考えらえるものとして, 以下が挙げ られる。

(1)作用応力（熱応力）

(2)TGO の成長

(3)トップコートの材質変化（焼結や相変化）

(4)エロージョン

次に，それぞれのメカニズムならびにそれを踏まえた 損傷評価技術についてまとめる.

\section{$3 \cdot 1$ 作用応力}

実機 GT 翼等で使用される TBC は, 冷却されている部 品に適用されることから, 表面の温度は高く, 一方, ボ ンドコート側は母材の許容メタル温度以下に制御され ており，圧縮応力場にあることが多い。このため， TBC の熱サイクル耐久性を評価する場合, 実機と同様に温度 勾配を付与した状態で評価することが多い。

図 10 に, レーザ加熱式熱サイクル試験装置 ${ }^{11)}$ をす。 $\mathrm{TBC}$ が施工された試験片は, 表面から $\mathrm{CO}_{2}$ レーザにより 加熱され, 一方, 裏面はインピンジメント冷却により空 冷され, 温度勾配が付与された状態で、加熱・冷却の熱 サイクルを繰り返し付与し, TBC のはく離耐久性を評価 する．試験中の表面温度は放射温度計により計測され， 試験片には熱電対が取り付けられ板厚方向の温度分布 が記録される。この試験は, 主として TBC の改良・開 発に用いられている.
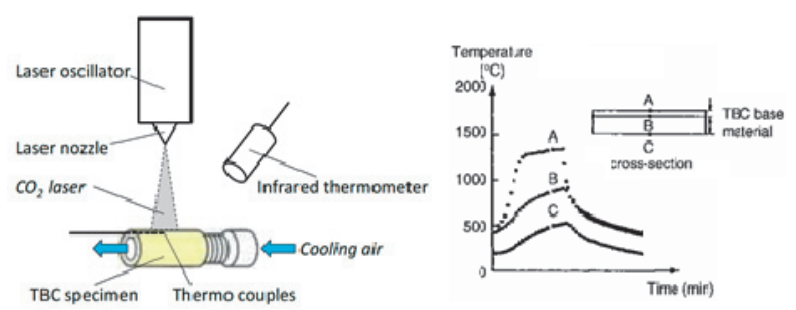

(a)試験の模式図

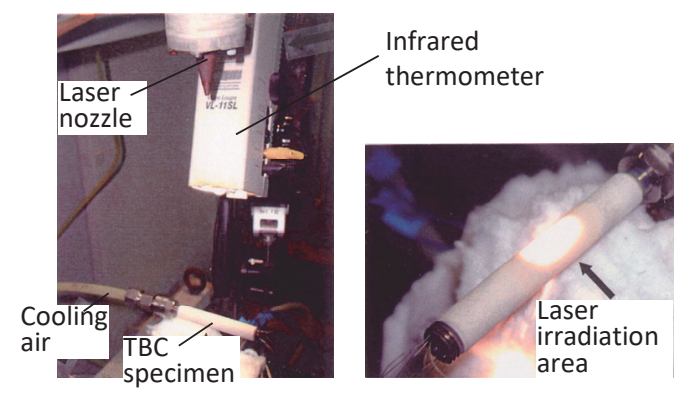

(b)試験状況

図 10 レーザ加熱式熱サイクル試験装置 ${ }^{11)}$ 
レーザ熱サイクル試験は，局所加熱により皮膜中に高 い温度勾配を TBC に付与することができる試験である が，機械荷重は重畳せず熱応力のみではく離させており, 実機環境とやや異なる。そこで，軸対象の温度分布を付 与しながら，機械荷重を重畳させることができ，実機に 近い熱一機械的環境を模擬できるイメージ炉熱サイク 儿試験装置が開発された。図 11 に, イメージ炉熱サイ クル試験装置 ${ }^{11)}$ を示す. 周方向温度分布が均一な状態で 板厚方向に温度勾配を付与でき, 機械ひずみを重畳可能 となっており, TBC 損傷の力学的メカニズム究明や寿命 評価研究に活用されている.

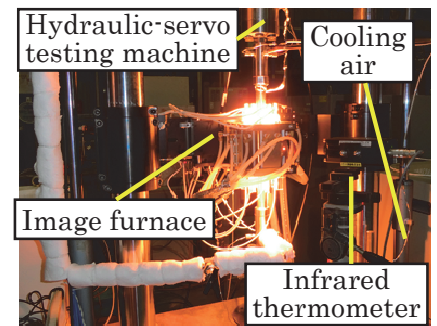

(a)試験状況

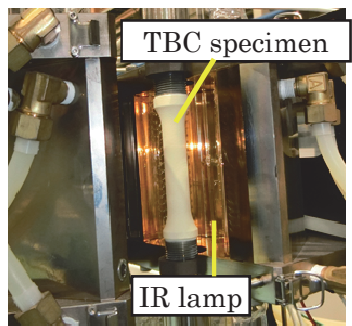

(b)試験片の外観
図 11 イメージ炬熱サイクル試験装置 ${ }^{11)}$

\section{$3 \cdot 2$ TGO}

図 12 に示す $\mathrm{TGO}$ は, ボンドコート中の $\mathrm{Al}$ 等の金属 元素が酸化された $\mathrm{Al}_{2} \mathrm{O}_{3}$ を主体とする酸化物であり，ボ ンドコート表面に生成・成長する.この TGO の成長は, トップコートに局所的な内部応力を与え, はく離を助長 するとされる。このため, GT メーカ等では, TBC の長 時間加熱を行い TGO の成長予測式を構築するとともに, TGO が生成した状態での熱サイクル試験を実施し, TGO 厚さと熱サイクル耐久性の関係を評価している。

一方，実機で使用された GT 翼は，第 2 章に示すよう に, 定期的に破壊調查され, その際に予測される形態や 厚さであるかなど, TGO の状況が確認・評価されている.

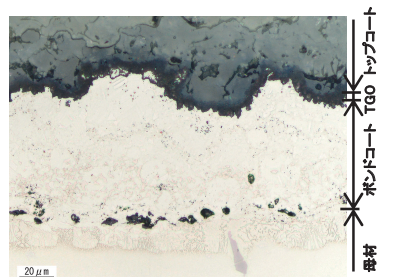

(a)光学顕微鏡

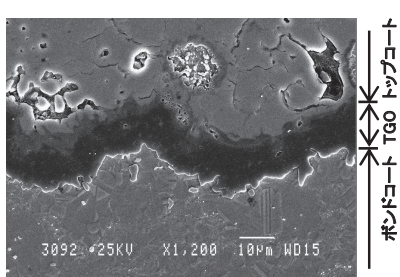

(b)SEM
図 $12 \mathrm{TBC}$ のボンドコート上に生成した TGO の例

\section{3·3 トップコートの材質変化}

TBC トップコート表面は高温に曝されるため, 材質変 化が生じる。図 13 に, Paul らが報告している APS 施工 による YSZ トップコートの $1400^{\circ} \mathrm{C} \times 10 \mathrm{~h}$ 加熱後の破面 の SEM 観察結果 ${ }^{12)}$ を示す。溶射まま材では溶射粒子が 扁平化したスプラットが明瞭に観察される，一方，加熱 材は，スプラット同士の癒着が生じており，焼結が生じ ていることが分かる．焼結の発生はヤング率の上昇を伴 (12), 皮膜の変形能の低下や発生応力の増加が生じる可 能性がある. 加えて, YSZ は部分安定化ジルコニアであ り， $1200^{\circ} \mathrm{C}$ 超える温度域では結晶変化を生じることが 報告 ${ }^{13)}$ されている．現在，これらトップコートの材質変 化を踏まえた TBC の寿命予測技術や，TBC の改良が進
められている.トップコートの焼結や相変化は，これま での発電用 GT ではTBCの表面温度が比較的抑えられて いることから問題になっていない. 今後, タービン入口 ガス温度の一層の上昇や, 冷却空気流量の低減等により, $\mathrm{TBC}$ の表面温度はこれまで以上に上昇すること考えら れる。一方，焼結や相変化は表面で生じる現象であり， その影響は少ない可能性もある. 焼結や相変化が $\mathrm{TBC}$ の信頼性／而久性に及ぼす影響に関しての報告は少な $<$, 今後の検討課題と考えられる.

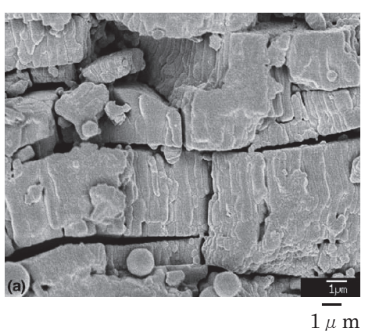

(a)溶射まま

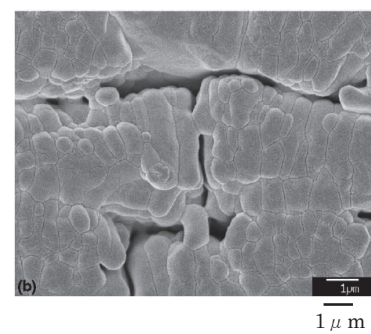

(b) $1400^{\circ} \mathrm{C} \times 10 \mathrm{~h}$ 加熱後
図 13 TBC の高温加熱に伴う破面形態の変化 ${ }^{12)}$

$3 \cdot 4$ エロージョン

発電用 GT では，吸気フィルタが設置されていること から, 異物の衝突による $\mathrm{TBC}$ の損傷は多くない. しか し，長時間の使用では配管内の錆等により TBC にエロ ージョンが生じる可能性も考えられる. エロージョンが 生じると膜厚の減少による遮熱効果低下が考えられる ため評価が必要となる. TBC のエロージョン特性を評価 するには, 可能な限り実機環境を模擬する必要がある.

そこで，実機環境下を模擬・再現したエロージョン試 験装置が開発され，評価に活用されている。図 14 に, 高温エロージョン試験装置 ${ }^{11)}$ を示す.

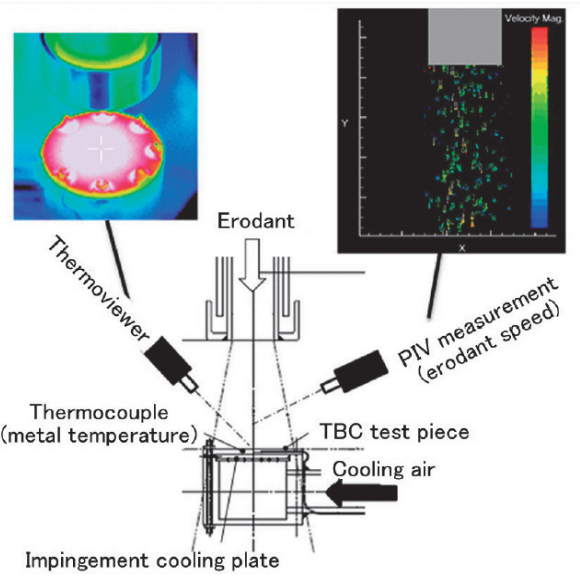

(a)試験装置の模式図

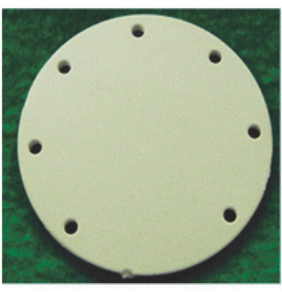

(ア)試験前

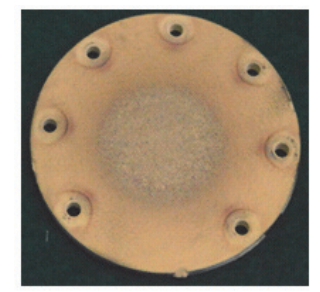

( 亻試験後 (b)試験前後の試験片の外観

図 14 高温エロージョン試験装置 ${ }^{11)}$ 
TBC 表面温度はサーモビュアにて, エローダント速度 は PIV（Particle Image Velocimetry）にて計測し，実機相 当の温度，粒子速度を実現している。評価は，試験前・ 後の試験片重量および表面形状変化を計測することで 行い, 得られたデータは, 実機 GT の TBC の状況と比較 し，実機での TBC のエロージョン特性の予測に活用さ れている。

\section{4 結言}

本講座では，発電用 GT 翼で使用された TBC の損傷, 損傷メカニズムおよびその評価手法の例について紹介 した. TBCの損傷・劣化要因は非常に複雑であるが, 実 機での事例を参照し，充分にその現象を理解するととも に，実機 GT において TBC に作用する力学的モード，材 質劣化メカニズムを再現することが重要である.

加えて，実機で想定される TBC の使用時間において 裕度をもって使用可能とするには，下記を考慮した継続 的な検討・評価が重要と考えられる.

(1)作用応力や材質変化が $\mathrm{TBC}$ の信頼性に及ぼす影響の 把握や損傷メカニズムの理解・解明

(2)材質変化メカニズムを反映した材質や皮膜構造の改 良による TBC の信頼性向上

(3)耐久性と遮熱性を両立する安定した施工技術

(4)使用温度や経年変化を加味した $\mathrm{TBC}$ 適用設計技術

(5)実機における TBC の使用状況の把握

\section{参 考 文 献}

1) T. Torigoe, I. Okada, E. Ito, I. Nagano, M. Shida, H. Oguma, K. Mori, K. Tsukagoshi and S. Kasumi, "Development of low thermal conductivity thermal barrier coating for the next generation $1700^{\circ} \mathrm{C}$ class gas turbine", Proceedings of the International Gas Turbine Congress, IGTC TS-085, pp.1-6 (2007).

2) K. Takamura, T. Iijima, S. Wakazono, S. Hada, M. Yuri and M. Kataoka, "Development of $1650{ }^{\circ} \mathrm{C}$ class next generation JAC gas turbine based on J experience", Mitsubishi Heavy Industries Technical Review, Vol.56, No.3, pp.1-9 (2019).

3) S. Bose and J. DeMasi-Marcin, "Thermal barrier coating experience in gas turbine engines at Pratt \& Whitney", Journal of Thermal Spray Technology, Vol.6, pp.99-104 (1997).

4) D. L. Ruckle and D.S. Duvall, "Quench-cracked ceramic thermal barrier coatings", U.S. Pat. No. 4,457,948 (1984).

5) T. Hino, W. Kono and S. Ito, "Development of repair method for damaged gas turbine blade", Journal of the Gas Turbine Society of Japan, Vol.40, No.4 pp.130-134 (2012).

6) A. Ito, "Degradation evaluation of long-term serviced $1300^{\circ} \mathrm{C}$-class 1 st stage gas turbine blade", Proceedings of the 52nd Symposium on Strength of Materials at High Temperature, pp.11-14 (2014).

7) A. Ito, Y. Kagiya, T. Torigoe and Y. Uemura, "Damage analysis and life evaluation of thermal barrier coatings", Proceedings of the 43rd Symposium on Strength of Materials at High Temperature, pp.162-165 (2005).

8) A. Ito, "Damage/Degradation of the DVC-TBC on a serviced gas turbine blade", Proceedings of the 65th JSMS Annual Meetings, pp.165-166 (2016).

9) W. A. Nelson, R. M. Orenstein and P. S. DiMascio,
"Development of advanced thermal barrier coatings for severe environments", Presented at the International Gas Turbine and Aero engine Congress and Exposition, 95-GT-270, pp.1-7 (1995).

10) C. G. Levi, J. W. Hutchinson, M. H. Vidal-Sétif and C. A. Johnson, "Environmental degradation of thermal barrier coatings by molten deposits", MRS Bulletin, Vol.37, pp.932-941 (2012).

11) K. Takeno, T. Karato, Y. Okajima, T. Torigoe, M. Mega and S. Horie, "Development of thermal barrier coating on high efficiency gas turbine", Proceedings of the 56th Symposium on Strength of Materials at High Temperature, pp.99-102 (2018).

12) S. Paul, A. Cipitria, I. O. Golosnoy, L. Xie, M. R. Dorfman and T.W. Clyne, "Effects of impurity content on the sintering characteristics of plasma-sprayed zirconia”, Journal of Thermal Spray Technology, Vol.16, pp.798-803 (2007).

13) R. Subramanian, A. Burns and W. Stamm, "Advanced multi-functional coatings for land-based industrial gas turbines", Proceedings of ASME Turbo Expo, GT2008-51532, pp.1-10 (2008). 